\title{
Saltgrass Clones' Spike Production Affected by Sampling Time, Nitrogen Fertilization, and Burning
}

\author{
Hrvoje Rukavina and Harrison G. Hughes ${ }^{1}$
}

ADDITIONAL INDEX WORDs. warm-season turfgrass, clones' origin, seed management, breeding

SuMmARY. Saltgrass (Distichlis spicata) has received increased attention as a result of its low input needs. A good understanding of the factors that influence greater flower production in saltgrass clones would facilitate seed production management and hybridization in the breeding program. Therefore, the influence of sampling time from the field, nitrogen $(\mathrm{N})$ fertilization, and burning on flowering spike production of five saltgrass clones from three cold-hardiness zones were evaluated over 2 years. Clones were sampled from the field at two times (August and November) in the first and at three times (August, November, and January) in the second experimental year. After field sampling, clones were transferred to the greenhouse and received $\mathrm{N}$ and burning treatments. $\mathrm{N}$ fertilization increased number of spikes (flowering) for all saltgrass clones by $\approx \mathbf{3 0 \%}$ in both experimental years. In the second experimental year, the number of spikes was increased to a greater extent when $\mathrm{N}$ was applied in combination with burning treatment as compared with $\mathrm{N}$ without burning. The burning treatment had a greater effect on the number of spikes in plants sampled in August as compared with those sampled in November and January. Sampling in November increased flowering in three clones as compared with August sampling, but with the greatest effect in clone A1540. Sampling in January further increased the number of spikes in clones 1490 and A1610 but with no significant effect on the number of spikes in clone A1540. Environmental adaptation associated with origin of saltgrass clones is a major factor that influences flowering spike production.

S altgrass is a warm-season grass with excellent drought, heat, and salinity tolerance (Kopec and Marcum, 2001; Rukavina, 2006). It is native to North America and commonly grows in saline and alkaline soils across the western United States (Eppley et al., 1998). Saltgrass has recently received increased attention because of its low input needs. As a result of rapid population growth in the semiarid U.S. west, there is public interest in using new turfgrass species that are water-efficient and tolerant of lowquality water (Rukavina et al., 2007). Evaluation of saltgrass accessions for potential turf use is an ongoing program at Colorado State University. The breeding program is focused on development of seeded turf-type saltgrass cultivars. Understanding factors that influence flower production and inflorescence development in saltgrass would improve seed production management and facilitate crossing in the breeding program.

Nutrients, particularly nitrogen (N) availability, influence flower production and seed yield in grass species (Sanderson et al., 2004). N fertilization increased the flowering tiller number and subsequent seed yield for warm-season grasses such as big bluestem (Andropogon gerardi) (Masters et al., 1993), gamagrass (Tripsacum dactyloides) (Lemke et al., 2003), and buffalograss (Buchloe dactyloides) (Abeyo et al., 2006). Fire is another important factor that influences greater flower production in many plant species (Bowen and Pate, 2004). Flowering after fire enables the plant to produce seeds that are much more likely to survive unfavorable conditions than the plant itself (Levy and Dean, 1998). Bowen and Pate (2004) reported significantly greater growth and flowering in blueboy (Stirlingia latifolia) after fire as compared with cutting and removal of plant tissue. Generally, burning increased flowering and seed yield of warm-season grasses like weeping lovegrass (Eragrostis curvula) (McFarland and Mitchell, 2000), big bluestem, and switchgrass (Panicum virgatum) (Sanderson et al., 2004). Photoperiod and vernalization (low temperatures) are the important factors that generally influence flower induction and development in plants (Simpson et al., 1999). In temperate grasses, exposure to short days and cold temperatures have equally important effects on flower induction and inflorescence development. For warm-season grasses, there is no welldefined vernalization requirement for flower induction and development, but photoperiod (short days) appears to be the key factor (Ashby and Hellmers, 1959; Van Esbroeck et al., 2004).

This study was initiated to evaluate the influence of sampling time from the field (the combined effect of photoperiod and vernalization), $\mathrm{N}$ fertilization, and burning treatment on flowering spike production in five saltgrass clones from three coldhardiness zones.

\section{Materials and methods}

Five saltgrass clones originating from three different cold-hardiness zones were evaluated over 2 years (Table 1). In each experimental year, the experiment consisted of initial field sampling followed by the greenhouse $\mathrm{N}$ and burning studies. Clones were established in $5 \times 5$-m field plots at the Colorado State University
Department of Horticulture and Landscape Architecture, Colorado State University, Fort Collins, CO 80523-1173

We thank Phillip Chapman for help in data analysis We also thank Yaling Qian and Leigh Towill for suggestions for the improvement of this manuscript, Sarah Wilhelm for help in experiment set up, and Dana Christensen for use of plant material.

${ }^{1}$ Corresponding author. E-mail: harrison.hughes@ colostate.edu.

\begin{tabular}{llll}
\hline $\begin{array}{l}\text { Units } \\
\text { To convert U.S. to SI, } \\
\text { multiply by }\end{array}$ & U.S unit & SI unit & $\begin{array}{l}\text { To convert SI to U.S., } \\
\text { multiply by }\end{array}$ \\
\hline 0.3048 & $\mathrm{ft}$ & $\mathrm{m}$ & 3.2808 \\
3.7854 & gal & $\mathrm{L}$ & 0.2642 \\
2.54 & inch $(\mathrm{es})$ & $\mathrm{cm}$ & 0.3937 \\
1.1209 & $\mathrm{lb} / \mathrm{acre}$ & $\mathrm{kg} \cdot \mathrm{ha}^{-1}$ & 0.8922 \\
1 & $\mathrm{ppm}$ & $\mathrm{mg} \cdot \mathrm{kg}^{-1}$ & 1 \\
$\left({ }^{\circ} \mathrm{F}-32\right) \div 1.8$ & ${ }^{\circ} \mathrm{F}$ & ${ }^{\circ} \mathrm{C}$ & $\left(1.8 \times{ }^{\circ} \mathrm{C}\right)+32$
\end{tabular}

Hartectmology · July-September 2008 18(3) 
Table 1. Saltgrass clones used in the study that considered spike production as influenced by sampling time, nitrogen fertilization, and burning, according to clone origin and U.S. Department of Agriculture cold-hardiness zone.

\begin{tabular}{llc}
\hline Clone & \multicolumn{1}{c}{ Place of origin } & Cold-hardiness zone $^{z}$ \\
\hline Al540 & Aurora, CO & 5 \\
1490 & Chamberlain, SD & 4 \\
C1660 & Humboldt Sink, NV & 6 \\
Al610 & Aurora, CO & 5 \\
A1 180 & Denver, CO & 5 \\
\hline
\end{tabular}

${ }^{2}$ The average minimum air temperature range in U.S. Department of Agriculture cold-hardiness zones 4,5 , and 6 are -28.9 to $-34.4^{\circ} \mathrm{C},-23.3$ to $-28.9^{\circ} \mathrm{C}$, and -17.7 to $-23.3{ }^{\circ} \mathrm{C}$, respectively $\left(1.8 \times{ }^{\circ} \mathrm{C}\right)+32={ }^{\circ} \mathrm{F}$.

Horticultural Research Center, Fort Collins, in July 1998. Field soil was a fine Nunn clay loam with a $\mathrm{pH}$ of 8.1 and an initial content of $23 \mathrm{mg} \cdot \mathrm{kg}^{-1}$ $\mathrm{N}, 14 \mathrm{mg} \cdot \mathrm{kg}^{-1}$ phosphorus, and 497 $\mathrm{mg} \cdot \mathrm{kg}^{-1}$ potassium (Shahba et al., 2003). Clones were replicated in the field twice in a randomized complete block design. Fertilizers were not applied and the field was mowed once per week at a height of $6 \mathrm{~cm}$. Irrigation was applied once a year in late July by flooding the field with $\approx 12$ $\mathrm{cm}$ of water. Clones Al540, 1490, and Cl660 were used in both experimental years. Clones Al180 and Al610, from the Colorado Front Range (the Colorado region that lies on the eastern foot of the Rocky Mountains), were added in the second year. All clones used in the experiment were female or pistillate with similar tiller density. Two-gallon plugs, $\approx 13 \mathrm{~cm}$ diameter and $18 \mathrm{~cm}$ tall, were sampled (dug up) for each clone from the field two times (midAugust and mid-November) in the first year (2003) and three times (mid-August, mid-November, and mid-January) in the second year (2004 to 2005) of the experiment. A third sampling time was added to test if longer exposure to short days and cold temperatures in the field stimulated an increase in spike number in clone 1490. Two new clones were included to determine if clones originating from the Colorado Front Range differed in requirements for optimal flower production. The latter test was performed because most of the saltgrass clones used in the breeding program are from the Colorado Front Range. The two additional clones were grown in the same site as the three other clones. After field sampling, the field clones were transferred to Colorado State University greenhouse and maintained in 2-gallon pots filled with field soil (clay loam). The average greenhouse temperature during the experiment was $\approx 21 \pm 2{ }^{\circ} \mathrm{C}$ with daylengths extended to $15 \mathrm{~h}$ using 430 -W high-pressure sodium lamps. After 1 week in the greenhouse, pots received $\mathrm{N}$ fertilization in one dose and burning treatments. Plants that received $\mathrm{N}$ fertilization received $200 \mathrm{~kg} \cdot \mathrm{ha}^{-1}$ of $\mathrm{N}$ equivalent from ammonium nitrate. The tops of those plants that received the burning treatment were burned to soil level with a handheld propane burner so that all aboveground tissue was consumed by the fire. Saltgrass tissue was green when burned in August but brown when sampled and burned in November and January.

The experimental design was a factorial randomized complete block with three blocks (repetitions). Final spike number (generally reflected in increased flowering of tillers) of each clone was determined for each treatment combination after $\approx 7$ weeks from treatment application. Mixed model analysis of variance (proc mixed) in SAS (v8; SAS Institute, Cary, NC) was used to determine which factors and which interactions among factors influenced number of spikes (flowering) in saltgrass. Clones, sampling time, $\mathrm{N}$ fertilization, burning treatment, and experimental year were treated as fixed factors and blocks were treated as a random factor. To ensure linearity and homogeneity of variance, the dependent variable (number of spikes) was transformed by using the natural logarithm scale with an added constant of two.

\section{Results and discussion}

Spikes appeared $\approx 5$ weeks after treatment in both years of the experiment. Because clones Cl660 from Nevada and Al180 from Colorado did not flower with any treatment used, they were not included in the statistical analysis. Highly significant effects on spike number were observed with clones, sampling time, $\mathrm{N}$ fertilization, and burning treatment. The effects of burning, N fertilization, and sampling time depended on experimental year. Significant interactions also occurred between clone and sampling time, clone and burning treatment, sampling time and burning treatment, and $\mathrm{N}$ fertilization and burning treatment (Table 2).

In the first experimental year, $\mathrm{N}$ fertilization produced a greater number of flowering tillers (Table 3 ). An increased number of spikes in clones Al540 and 1490 occurred when sampling was done in November as compared with August. However, this increase was greater in clone $\mathrm{Al} 540$ than in clone 1490. Similarly, the effect of burning on number of spikes was greater in clone 1540 than in clone 1490. Burning treatment significantly increased number of spikes (flowering) only in plants sampled from the field in August. Burning had no significant effect on number of spikes in those plants sampled in November (Table 3 ).

In the second experimental year, $\mathrm{N}$ fertilization increased the number of spikes in all clones but was greatest when $\mathrm{N}$ was applied in combination with the burning (Table 4). This finding is similar to that of Masters et al. (1993) who reported that the combined effect of fire and $\mathrm{N}$ fertilizer increased seed yield of indiangrass (Sorghastrum nutans) to a greater extent than fertilizer alone. Lamb and Murray (1999) found that field burning increased efficiency of fertilizer in kentucky bluegrass (Poa pratensis) seed production.

Saltgrass clones responded differently to sampling time (combined effect of photoperiod and vernalization). The November sampling time significantly increased number of spikes (flower production) as compared with sampling in August in all clones with the greatest increase in clone A1540. The January sampling time further significantly increased the number of spikes in clones 1490 and Al610 above that of those sampled in November. Sampling in January had no significant effect on number of spikes in clone Al540 as compared with sampling in November. Burning increased the number of spikes in all three sampling 
times and clones; the increase was the greatest in plants sampled in August and in clone A1540 (Table 4).

Overall, there was variation in flowering in the saltgrass clones.
Clone C1660 collected from Nevada flowered continuously during the summer in the field in both seasons of the experiment but either did not flower in the greenhouse with any of

Table 2. Analysis of variance of the effects of experimental year, clone, sampling time, nitrogen $(\mathrm{N})$ fertilization, burning, and their interactions on spike number in saltgrass.

\begin{tabular}{|c|c|}
\hline Source of variability & $P^{\mathrm{z}}$ \\
\hline Year & 0.3037 \\
\hline Clone & $<0.0001$ \\
\hline Year $\times$ clone & 0.6623 \\
\hline Sampling time & $<0.0001$ \\
\hline Year $\times$ sampling time & 0.0096 \\
\hline Clone $\times$ sampling time & $<0.0001$ \\
\hline Year $\times$ clone $\times$ sampling time & 0.6302 \\
\hline $\mathrm{N}$ fertilization & $<0.0001$ \\
\hline Year $\times \mathrm{N}$ fertilization & 0.0152 \\
\hline Clone $\times \mathrm{N}$ fertilization & 0.5522 \\
\hline Year $\times$ clone $\times \mathrm{N}$ fertilization & 0.0273 \\
\hline Sampling time $\times \mathrm{N}$ fertilization & 0.2249 \\
\hline Year $\times$ sampling time $\times \mathrm{N}$ fertilization & 0.8864 \\
\hline Clone $\times$ sampling time $\times \mathrm{N}$ fertilization & 0.0975 \\
\hline Year $\times$ clone $\times$ sampling time $\times \mathrm{N}$ fertilization & 0.4648 \\
\hline Burning & $<0.0001$ \\
\hline Year $\times$ burning & 0.0380 \\
\hline Clone $\times$ burning & $<0.0001$ \\
\hline Year $\times$ clone $\times$ burning & $<0.0001$ \\
\hline Sampling time $\times$ burning & $<0.0001$ \\
\hline Year $\times$ sampling time $\times$ burning & 0.1533 \\
\hline Clone $\times$ sampling time $\times$ burning & 0.0784 \\
\hline Year $\times$ clone $\times$ sampling time $\times$ burning & 0.7578 \\
\hline $\mathrm{N}$ fertilization $\times$ burning & 0.0077 \\
\hline Year $\times \mathrm{N}$ fertilization $\times$ burning & 0.1651 \\
\hline Clone $\times \mathrm{N}$ fertilization $\times$ burning & 0.4623 \\
\hline Year $\times$ Clone $\times \mathrm{N}$ fertilization $\times$ burning & 0.6788 \\
\hline Sampling time $\times \mathrm{N}$ fertilization $\times$ burning & 0.4521 \\
\hline Year $\times$ sampling time $\times \mathrm{N}$ fertilization $\times$ burning & 0.8767 \\
\hline Clone $\times$ sampling time $\times \mathrm{N}$ fertilization $\times$ burning & 0.3215 \\
\hline Year $\times$ clone $\times$ sampling time $\times \mathrm{N}$ fertilization $\times$ burning & 0.6730 \\
\hline
\end{tabular}

the treatments or responded with only a very few spikes. This study did not separate the individual effects of photoperiod and vernalization. Although photoperiod appears to play the key role in flower induction and development in warm-season grasses, saltgrass clones from cooler climates may also have a vernalization requirement. Genetic adaptation of clone $\mathrm{C} 1660$ to warmer climates is likely related to flowering induction by long daylengths during the late spring and early summer without exposure to cold temperatures. Ashby and Hellmers (1959) reported that several warm-season grasses from southern California required only a short vernalization period for flowering. Our finding is also similar to that of the cool-season annual bluegrass (Poa annua) (Johnson and White, 1997a, 1997b). In those experiments, long-day photoperiods induced flowering in some annual bluegrass genotypes that were not sensitive to imposed vernalization treatments.

Flowering of clones Al540 and 1490 in both experimental years was likely stimulated by exposure to low temperatures or short day conditions. However, in the first experimental year, clone A1540 developed a greater number of spikes than clone 1490. This suggested that different clones may have different environmental requirements to maximize spike number. Indeed, exposure to low temperatures and shorter days until January in the second experimental season significantly increased the number of spikes in clone 1490 with little increase in clone A1540.

Table 3. Differences between selected least square means of nitrogen $(\mathrm{N})$ fertilization and interactions between saltgrass clone and burning and sampling time and burning in the first experimental year.

\begin{tabular}{|c|c|c|c|c|c|}
\hline \multirow{2}{*}{$\frac{\text { Effect }}{\mathrm{N} \text { fertilization }}$} & \multicolumn{2}{|c|}{ Least square means compared (no. spikes) ${ }^{\mathrm{z}}$} & \multirow{2}{*}{$\begin{array}{c}\begin{array}{c}\text { Difference } \\
\text { (no. spikes) }\end{array} \\
8\end{array}$} & \multirow{2}{*}{$\frac{\text { t statistic }}{5.43}$} & \multirow{2}{*}{$\frac{P^{\mathbf{y}}}{<0.0001}$} \\
\hline & Fertilizer applied (16) & Fertilizer not applied (8) & & & \\
\hline Clone $\times$ sampling time & 1490 November $(9)$ & 1490 August (4) & 5 & 4.99 & $<0.0001$ \\
\hline Clone $\times$ burning & $\begin{array}{l}\text { Al540 burning } \\
\text { applied ( } 34)\end{array}$ & $\begin{array}{l}\text { Al540 burning } \\
\text { not applied (13) }\end{array}$ & 21 & 5.35 & $<0.0001$ \\
\hline Sampling time $\times$ burning & August burning applied (8) & $\begin{array}{l}\text { August burning } \\
\text { not applied (4) }\end{array}$ & 4 & 4.27 & 0.0002 \\
\hline Sampling time $\times$ burning & $\begin{array}{l}\text { November burning } \\
\text { applied }(25)\end{array}$ & $\begin{array}{c}\text { November burning } \\
\text { not applied }(24)\end{array}$ & 1 & 0.03 & 0.9737 \\
\hline
\end{tabular}

${ }^{2}$ Values in parentheses present the least square means that were back-transformed after transformation in logarithm scale.

${ }^{y}$ The level of significance was 0.05 . Differences with a probability less than 0.05 were considered significant. 
Table 4. Differences between selected least square means of interactions between nitrogen ( $\mathrm{N}$ ) fertilization and burning, saltgrass clone and sampling time, and sampling time and burning in the second experimental year.

\begin{tabular}{|c|c|c|c|c|c|}
\hline \multirow{2}{*}{$\frac{\text { Effect }}{\mathrm{N} \text { fertilization } \times \text { burning }}$} & \multicolumn{2}{|c|}{ Least square means compared (no. spikes) ${ }^{\mathrm{z}}$} & \multirow{2}{*}{$\begin{array}{c}\begin{array}{c}\text { Difference } \\
\text { (no. spikes) }\end{array} \\
6\end{array}$} & \multirow{2}{*}{$\frac{\text { t statistic }}{6.98}$} & \multirow{2}{*}{$\frac{P^{\mathrm{y}}}{<0.0001}$} \\
\hline & $\begin{array}{l}\text { Fertilizer applied with } \\
\text { burning (18) }\end{array}$ & $\begin{array}{l}\text { Fertilizer applied without } \\
\text { burning }(12)\end{array}$ & & & \\
\hline Clone $\times$ sampling time & Al540 November $(54)$ & Al540 August (9) & 45 & 23.27 & $<0.0001$ \\
\hline Clone $\times$ sampling time & Al540 January $(64)$ & Al540 November $(54)$ & 10 & 2.34 & 0.0221 \\
\hline Clone $\times$ sampling time & 1490 November $(8)$ & 1490 August (4) & 4 & 8.23 & $<0.0001$ \\
\hline Clone $\times$ sampling time & Al610 January (15) & Al610 November $(7)$ & 8 & 9.36 & $<0.0001$ \\
\hline Sampling time $\times$ burning & August burning applied (7) & $\begin{array}{l}\text { August burning not } \\
\text { applied (3) }\end{array}$ & 4 & 12.13 & $<0.0001$ \\
\hline Sampling time $\times$ burning & $\begin{array}{l}\text { November burning } \\
\text { applied (18) }\end{array}$ & $\begin{array}{l}\text { November burning } \\
\text { not applied (12) }\end{array}$ & 6 & 6.74 & $<0.0001$ \\
\hline Sampling time $\times$ burning & $\begin{array}{l}\text { January burning } \\
\text { applied }(30)\end{array}$ & $\begin{array}{l}\text { January burning } \\
\text { not applied }(20)\end{array}$ & 10 & 7.26 & $<0.0001$ \\
\hline
\end{tabular}

${ }^{2}$ Values in parentheses present the least square means that were back-transformed after transformation in logarithm scale.

y The level of significance was 0.05 . Differences with a probability less than 0.05 were considered significant.

This suggests that clone 1490 requires longer exposure to short days or low temperatures to maximize the number of spikes. On the other hand, a shorter exposure to low temperature/short day conditions can maximize spike number in clone Al540. Differences between these two clones are likely attributed to their origin. Clone 1490 is from Chamberlain, $\mathrm{SD}$, and clone Al540 from the Colorado Front Range (Denver area), a climate with less harsh winters and a longer growing season. Requirements for optimal flowering in North American native grasses with wide geographical distribution often vary within species (Van Esbroeck et al., 2003). Northern switchgrass cultivars showed greater sensitivity to extended photoperiod resulting in a longer vegetative phase as compared with southern cultivars (Van Esbroeck et al., 2003). Our finding is also consistent with results observed in some temperate grasses like kentucky bluegrass (Carlson et al., 1995) and alpine bluegrass (Poa alpina) (Pahl and Darroch, 1997). In both of those studies, genotypes from warmer climates required a shorter time of low temperatures/short daylengths than genotypes from northern areas to maximize flowering.

Clones Al540 and Al610 from the Colorado Front Range differed in their environmental conditions for maximum flowering. Although clone Al540 achieved maximum flowering in late November, clone Al610 required an additional period of cold temperatures/short days for maximum flowering. The Colorado Front Range is composed of many microenvironments. These heterogeneous microclimates would likely lead to environmental adaptation of important traits (e.g., requirements for flowering) causing within-population variability as similarly observed in blue grama (Boutelona curtipendula) (Van Esbroeck et al., 2003) and alpine bluegrass (Pahl and Darroch, 1997). Clone Al180 from the Colorado Front Range did not flower with the treatments used. Hughes et al. (2002) reported that some male and female saltgrass clones from the same geographical region flower abundantly, whereas many others do not. This likely reflects the diversity of genetic background relative to flowering.

Our results indicate that $\mathrm{N}$ fertilization is an important factor that quantitatively stimulates flowering in saltgrass. In this study, $\mathrm{N}$ stimulated an increase in spike number in saltgrass regardless of the timing of collection from the field or origin of clone. Similarly, N fertilization has been reported to increase tiller density, flowering, and subsequent seed yield in many U.S. native warm-season grasses (Cornelius, 1950; Masters et al., 1993).

Saltgrass responds to fire by rapidly regenerating new shoots from rhizomes (Hauser, 2006). The effect of fire (burning treatment) on spike number in saltgrass clones seems to be associated with the season of burning application. Burning treatment had a greater effect on flowering (spike number) in saltgrass clones sampled from the field in August as compared with the burning effect on plants sampled in November and January. Presumably, the factors associated with season of burn such as climatic conditions experienced after the fire influence shoot recovery and subsequent flowering. Our findings are similar to a flowering production study in blackboy or grasstree (Xanthorrhoea preissii) (Lamont et al., 2000). In that study, a summer burn had significantly greater effect on flowering as compared with winter burn. Similarly, summer burn stimulated flowering in blueboy to a greater extent than winter burn (Bowen and Pate, 2004).

In summary, our results indicate that environmental adaptation associated with origin of clone is a major factor influencing flowering and spike number in saltgrass. Length of exposure to short day or low temperature was likely an important factor influencing differences in spike number among saltgrass clones from different geographic regions. $\mathrm{N}$ fertilization increases number of spikes in saltgrass regardless of clone origin or sampling time from the field. The effect of burning on number of spikes varies with application time. Burning had the greatest effect on number of spikes in August. It also increases the effect of fertilizer on flower production. The knowledge of requirements for optimal flower production of 
particular saltgrass clones may facilitate saltgrass seed production management and hybridization in a saltgrass breeding program.

\section{Literature cited}

Abeyo, B.G., R.C. Sherman, C.J. Schmid, and L.A. Wit. 2006. Enhancement of buffalograss seed production by fertilizer. 13 Sept. 2007. <http://a-c-s.confex. com/crops/2006am/techprogram/ P24242.HTM>.

Ashby, C.W. and H. Hellmers. 1959. Flowering and growth response to photoperiod and temperature for six southern California grasses. Bot. Gaz. 120:151157.

Bowen, B.J. and J.S. Pate. 2004. Effect of season of burn on shoot recovery and post fire flowering performance in Stirlingia latifolia R. Br. (Proteaceae). Austral Ecol. 29:145-155.

Carlson, J.M., N.J. Ehlke, and D.L. Wyse. 1995. Environmental control of floral induction and development in kentucky bluegrass. Crop Sci. 35:1127-1132.

Cornelius, D.R. 1950. Seed production of native grasses under cultivation in eastern Kansas. Ecol. Monogr. 20:1-29.

Eppley, S.M., M.L. Stanton, and R.C. Grosberg. 1998. Intrapopulation sex ratio variation in the salt grass Distichlis spicata. Amer. Naturalist 152:659-670.

Hauser, A.S. 2006. Species: Distichlis spicata. 28 Aug. 2007. <http://www.fs.fed.us/data base/feis/plants/graminoid/disspi/ introductory.html $>$.

Hughes, H.G., D.K. Christensen, A.J. Koski, and S.D. Reid. 2002. Desert saltgrass: A potential new turfgrass. 6 Sept.
2007. <http://turf.lib.msu.edu/tero/ $\mathrm{v} 01 / \mathrm{nl} 2 . \mathrm{pdf}>$.

Johnson, P.G. and D.B. White. 1997a. Vernalization requirements among selected genotypes of annual bluegrass (Poa annua L.). Crop Sci. 37:15381542 .

Johnson, P.G. and D.B. White. 1997b. Flowering responses of selected annual bluegrass genotypes under different photoperiod and cold treatments. Crop Sci. 37:1543-1547.

Kopec, D.M. and K. Marcum. 2001. Desert saltgrass: A potential new turfgrass species. U.S. Golf Assn. Green Section 39:6-8.

Lamb, P.F. and G.A. Murray. 1999. Kentucky bluegrass seed and vegetative response to residue management and fall nitrogen. Crop Sci. 39:1416-1423.

Lamont, B.B., P.W. Swanborough, and D. Ward. 2000. Plant size and season of burn affect flowering and fruiting of the grasstree Xanthorrhoea preissii. Austral Ecol. 25:268-272.

Lemke, B.M., L.R. Gibson, A.D. Knapp, P.M. Dixon, K.J. Moore, and R. Hintz. 2003. Maximizing seed production in eastern gamagrass. Agron. J. 95:863-869.

Levy, Y.Y. and C. Dean. 1998. The transition to flowering. Plant Cell 10:19731989.

Masters, R.A., R.B. Mitchell, K.P. Vogel, and S.S. Waller. 1993. Influence of improvement practices on big bluestem and indiangrass seed production in tallgrass prairies. J. Range Manage. 46:183-188.

McFarland, B.J. and R. Mitchell. 2000. Fire effects on weeping lovegrass tiller density and demographic. Agron. J. 92:42-47.

Pahl, M. and B. Darroch. 1997. The effect of temperature and photoperiod on primary floral induction in three lines of alpine bluegrass. Can. J. Plant Sci. 77: 615-622.

Rukavina, H. 2006. Phenotypic variability, cold hardiness and flowering induction of saltgrass [Distichlis spicata (L.) Greene] clones. Colorado State Univ., Fort Collins, PhD Diss. UMI 3246305.

Rukavina, H., H.G. Hughes, and Y.L. Qian. 2007. Freezing tolerance of 27 saltgrass ecotypes from three cold hardiness zones. HortScience 42:157-160.

Sanderson, M.A., R.R. Schnabel, W.S. Curran, W.L. Stout, D. Genito, and B.F. Tracy. 2004. Switchgrass and big bluestem hay, biomass, and seed yield response to fire and glyphosate treatment. Agron. J. 96:1688-1692.

Shahba, M.A., Y.L. Qian, H.G. Hughes, D. Christensen, and A.J. Koski. 2003. Cold hardiness of saltgrass accessions. Crop Sci. 43:2142-2147.

Simpson, G.C., A.R. Gendall, and C. Dean. 1999. When to switch to flowering. Annu. Rev. Cell Dev. Biol. 99:519-550.

Van Esbroeck, G.A., M.A. Hussey, and M.A. Sanderson. 2003. Variation between alamo and cave-in-rock switchgrass in response to photoperiod extension. Crop Sci. 43:639-643.

Van Esbroeck, G.A., M.A. Hussey, and M.A. Sanderson. 2004. Reversal of dormancy in switchgrass with low-light photoperiod extension. Bioresour. Technol. 91:141-144. 